\title{
Natural Conditioning of the Spiritual Life: A Contribution to Methodological Reflection
}

\author{
KRZYSZTOF MATUSZEWSKI \\ University of Silesia in Katowice, Poland \\ krzysztof.matuszewski@us.edu.pl, ORCID: 0000-0003-4615-8578
}

\begin{abstract}
The spiritual life constitutes an integral experience of any person being led by the Holy Spirit toward full communion with God. It is never something abstract, divorced from Sitz im Leben, in either the psychological aspect or the socio-cultural dimension, thus it always bears certain signs of one's temperament, environment, and history. The present paper proposes a methodology of research into the natural basis of the spiritual life (psychological and socio-cultural), which influences the way God's grace is received and experienced. The natural structures of the spiritual life constitute the ground, which is submitted to God's salvific action and bears fruit in various forms. The description of the spiritual life demands the use of the appropriate methodology, which can be based on the combination of the doctrinal-sapiential (deductive) approach and the existential-anthropological (inductive) approach. An important auxiliary role in the description of the spiritual phenomenon can be played by psychological methods, for instance those that derive from the psycho-biographical approach, which allows us to capture what is unique in human functioning.
\end{abstract}

Keywords: methodology of spiritual theology, the spiritual life, natural structures of the spiritual life, psychological conditioning, socio-cultural conditioning

The expression "natural conditioning of the spiritual life" may raise a red flag, depending on the reader's theological sensitivity. Does the author aim at reducing the whole experience of Christian spirituality to a purely natural dimension, treating it as a symptom of psychic life? ${ }^{1}$ Benito Goya answers this question in his monograph Psicologia e vita spirituale. Sinfonia a due mani, in which he tries to demonstrate connections between the natural life and the supernatural life. He starts with reminding readers of the priority of grace, emphasizing the fact that the fullness of humanity is achievable only in God. At the same time, he is of the opinion that strong human grounds facilitate the creation of a stable and free spiritual structure. In that structure, there is a harmonious cooperation or synergy between the two levels: of creation and

1 An example of the methodology presented in this paper is described and applied in the monograph: $W$ zderzeniu z natura - świętość Brata Alberta, where I explain in detail what conditioned the particular structures of Saint Brother Albert Chmielowski's spiritual life. In the present article, I discuss the methodology of research itself and present some results of the analyses, hoping that they can be used to study various spiritual profiles. 
of salvation, between the human background and the call to holiness. ${ }^{2}$ When trying to present the methodology of research on the natural grounds of the spiritual life, it seems necessary to define the basic notions precisely. Thanks to that, our analysis of the spiritual life in both the "top-down" way (starting with the sources of Revelation) and the "down-top" way (starting with the existential-anthropological perspective) will allow us to employ the appropriate research tools. ${ }^{3}$

The proposition to use the methodology and tools from non-theological disciplines of science to describe the spiritual experience gives us an opportunity not only to observe the subject of analysis from various perspectives. The point is to realize the papal postulate to renew ecclesiastical studies, which emphasizes inter - and cross-disciplinarity, understood as "the vital intellectual principle of the unity in difference of knowledge and respect for its multiple, correlated and convergent expressions." 4 In line with the above-mentioned criterion, all knowledge should be placed and developed "against the backdrop of the Light and Life offered by the Wisdom streaming from God's Revelation." Taking into account the criterion of cross-disciplinarity and employing achievements of other disciplines to describe the phenomenon of the spiritual life does not mean ignoring the vertical dimension and limiting everything to the horizontal dimension. It can help understand better the whole richness of expression of one's Christian spirituality in its various forms. ${ }^{6}$

\section{The Correlational Unity of Nature and Grace}

The natural conditioning of the spiritual life requires recalling basic dogmatic decisions concerning the relations between nature and supernaturality. In the history of theology, in one of extreme approaches, grace was reduced to nature, which resulted in losing the free favor of God, and the gift of grace became something necessarily appendant to man. That kind of approach violated the freedom of both God and man. At the opposite extreme there was the complete separation of nature and

2 See Goya, Psicologia e vita spirituale, 5-7.

3 The terms "spiritual experience" and "spiritual life," which are used in this paper as synonyms, are not identical. The spiritual life does not constitute a sum of spiritual experiences, although it is expressed in individual spiritual experiences. Thus, it is a broader term, describing the totality of the cooperation between man and the grace of the Holy Spirit. Cf. Chmielewski, "Życie duchowe," 975-978.

4 Francis, Veritatis Gaudium, 4. Inter - and cross-disciplinarity constitute the fourth of "the fundamental criteria for a renewal and revival of the contribution of ecclesiastical studies to a Church of missionary outreach" (ibidem).

5 Francis, Veritatis Gaudium, 4.

6 See Matanić, La spiritualità come scienza, 42-43. 
grace, where the latter became something distant and additional to the self-sufficient human nature. ${ }^{7}$

The contemporary approach emphasizes the separation of nature and grace, but also their correlational unity, in which the human nature is directed towards grace and refined by it, develops to reach its own fullness. ${ }^{8}$ Thus, the approach is concerned with the correlation of the two realities, which are understood as complementary. The juxtaposition of nature and supernaturality allows us to distinguish between what God gives us in the gift of creation and what man receives in the gift of redemption. The documents of the Second Vatican Council avoid the terms "natural" and "supernatural," or "nature" and "grace," but they point at a specific person, who, thanks to grace, can answer the invitation to participate in God's life. The grace of creation and the grace of salvation constitute two gifts of God, which are connected to each other. ${ }^{9}$ Luis Ladaria writes about two levels of grace, which causes numerous difficulties in the description of the spiritual life. It becomes impossible to distinguish precisely between what is natural and resulting from the condition of being a creation and what results from the grace of salvation. Those two dimensions are present in human experiences in such a way that they cannot be separated. ${ }^{10}$

In Polish theology, there is a good postulate presented by Andrzej Zuberbier who suggests describing the relation nature - supernaturality by analogy with interpersonal relationships, in line with the spirit of the Second Vatican Council. This approach allows us to see both man in specific historical conditions and God who calls man to unity in love. The interpersonal understanding of the relations between nature and supernaturality seems to be obvious when the two sides of the relation (God - man) are not treated in an abstract, speculative way, but in an existential and specific way. ${ }^{11}$

In Christian spirituality, we face the danger of taking extreme approaches, connected to overemphasizing either nature or grace. Among those dangerous approaches there is naturalism and its version called psychologism, which deprives man from mystery and the possibility of becoming sanctified, reducing the spiritual life to mental states. ${ }^{12}$ On the opposite side of the continuum there is supernaturalism (spiritualism), which ignores natural conditioning of the spiritual life and overemphasizes the supernatural reality. Spiritualism depreciates everything that does not come from the supernatural sphere, and at the same time, it disrespects the logic of salvation and Jesus Christ's Incarnation. The exclusion of the laws of physics and psychology, which define creation, results in the loss of realism in the judgement of one's spiritual

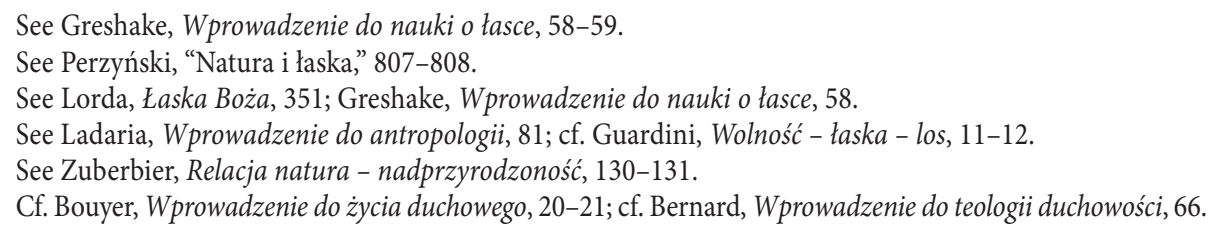


life. ${ }^{13}$ Taking into account the risk of the above-mentioned oversimplifications, it is necessary to remember that the description of the spiritual experience does not concern an abstract human nature (natura pura), but the experience of a specific person who has his or her story of life, a set of characteristics, and specific conditioning. Thus, it seems more appropriate to choose such methods that allow us to highlight the individual or subjective dimension of experiences. The natural dimension is always measurable to a certain degree, though in a limited way, unlike God's grace, which remains intangible from the empirical point of view.

Charles André Bernard emphasizes the complementarity of grace and natural structures. The latter are treated by him as dynamisms that constitute essential elements of the human person and influence one's development, combining external factors and structures constituting that person. ${ }^{14}$ In Polish studies concerning the conditioning of spirituality, we find works of Stanisław Witek who writes that natural aspects of the spiritual life require attention because God's grace is based on them and dignifies them. ${ }^{15}$ In contemporary views, the formation to holiness is to some extent conditioned by more or less favorable natural factors. ${ }^{16}$ Consequently, the way of receiving God's grace by man will be the resultant of different variables, for instance, the person's temperament, the structure of one's personality traits, the personal experiences, the historical background of one's life, as well as the spiritual theology dominating in the person's environment. It means that it is possible to demonstrate the connections between what is supernatural and what is natural. ${ }^{17}$

The psychological and socio-cultural conditioning as such is unable to reveal the deepest truth of the spiritual life, which is the divinization of man, but in line with C.A. Bernard's postulate, we do not diminish the power and goodness of God when we analyze all the natural factors that may influence the spiritual experience. ${ }^{18}$ When analyzing those natural factors, both individual and environmental, it is necessary to accept that they are stable and dynamic at the same time. The natural structures, both psychological and environmental, are changeable and they interact with each other. Their dynamic nature results in the fact that all kinds of analysis of the complex and layered structure of the spiritual life are based on probability, and never on a definite judgment. ${ }^{19}$

13 See Witek, Teologia życia duchowego, 152; Imoda, Odkryj w sobie tajemnice, 52. Cf. J. Szymik, Teologia, 40; Rulla - Imoda - Ridick, Antropologia della vocazione, 9-10.

14 Bernard, Wprowadzenie do teologii duchowości, 63.

15 Witek, Teologia życia duchowego, 133. Before Vaticanum II, Polish authors used the term "natural" with reference to the anthropological and cultural grounds of spirituality. See Bernard od Matki Bożej, Duchowość Brata Alberta, 108-110.

16 See Catalan, Esperienza spirituale, 117.

17 See Stinissen, Noc jest mi świattem, 71-72.

18 Bernard, Wprowadzenie do teologii duchowości, 68.

19 See Bernard, Teologia spirituale, 240-241. 


\section{The Doctrinal-Sapiential Approach}

Spiritual theology employs various methods, depending on the point of emphasis. In the doctrinal-sapiential approach, ${ }^{20}$ the starting point is the "top-down" theological perspective. In the analysis of the spiritual life the "research material" is juxtaposed with the model originating in the Bible and Tradition. The doctrine that is developed in such a way is speculative and normative. It describes the spiritual life as such, as well as the laws governing it. ${ }^{21}$ An example of that approach is Réginald Garrigou-Lagrange's The Three Ages of the Interior Life, which describes in detail the stages of spiritual development. ${ }^{22}$ According to Stanisław Urbański, the work of that French Black Friar constitutes a synthesis of the spiritual life which focuses on the concept of supernaturality ${ }^{23}$; thus, a person's individual character and one's psychological and environmental conditioning are excluded from the area of the author's interest.

The "top-down" (deductive) approach reflects the nature of theology as a discipline based on Revelation in a better way than the "down-top" (inductive) approach. However, the conclusions drawn in that approach are more general and abstract, and as a result, they overlook the experience and possibilities of a person living in a specific historical context. Nevertheless, deductive methods play an important role in the description of the spiritual experience because they defend us against the dangers of subjectivism. Setting the rules of the spiritual life helps the community of believers, who rely on the experience of the faith of the Church. ${ }^{24}$ Unfortunately, making justified and valid references to the spiritual tradition has some limitations. Great classical syntheses of the development of the spiritual life are marked by the era, in which they were created. Apart from that, their authors willingly use concepts from the past, which were usually shaped in a different historical context. Thus, it seems impossible to identify absolute rules and one precisely defined classification system (e.g. concerning the course of the mystical journey) because we are unable to take into account the whole of the spiritual experience in the constantly changing historical circumstances. ${ }^{25}$

20 In Polish works, the term "doctrinal-sapiential" is used, among others, by Marek Chmielewski (Metodologiczne problemy, 166-171), and by Stanisław Urbański ("Metodologia teologii duchowości," 230), who makes references to his work. That term points to the "normative" approach to spirituality, understood as a spiritual doctrine with the sapiential and pedagogical sense, including the description of the laws regulating the spiritual life and the duties that result from it.

21 See Chmielewski, Metodologiczne problemy, 166-172.

22 See Garrigou-Lagrange, Trzy okresy, 6.

23 Urbański, "Przedmowa," 6-7.

24 See Bernard, Wprowadzenie do teologii duchowości, 45.

25 See Bernard, Wprowadzenie do teologii duchowości, 45-46. 


\section{The Existential-Anthropological Approach}

A study on the spiritual life should always be conducted in correspondence with the basic experience described in the Bible and the Christian spiritual tradition, but it cannot be conducted in abstracto. In his article titled "Potrzeba metodologii w teologii duchowości," Marek Chmielewski considers the phenomenological approach to be the most adequate method to capture the uniqueness of the examined subject's spiritual experience. ${ }^{26}$ The point is to describe a phenomenon in a way that is not conditioned by any prior assumptions. Using phenomenology in psychology allows us to notice how rich and varied the spiritual life is when it comes to its forms. Thus, a research project assuming the existential-anthropological approach should follow the "down-top" way, starting with man and all dimensions of his existence. ${ }^{27}$ According to Jan Słomka, phenomenology allows us to capture the subjective dimension of the spiritual life, which is the human experience. ${ }^{28}$ In the phenomenological description we study what is subjective with the use of properly selected rules, although this description is difficult to formalize. The starting point is the original and somehow intuitive view on experience, which allows us to capture its individual character. In the next stage, theologians use their knowledge and skills in order to describe the character of the spiritual experience and to identify relationships and differences between it and other experiences. The spiritual experience encompasses first of all the individual experience, including the experience of the community and environment, in which the person lives. All the human aspects, together with the whole social context, may be subject to a phenomenological description. ${ }^{29}$

\section{A Comprehensive Method}

The demonstration of the correlational unity between nature and grace, which results in the orthodox understanding of the natural conditioning of the spiritual experience, and paying attention to the deductive and inductive approach to research on the spiritual experience constitute the basis for the selection of the adequate tools for highlighting the subjective aspects of spirituality. A way of conducting an analysis which offers the possibility to capture numerous dynamisms shaping the spiritual life seems to be beneficial. The first stage of the analysis is an attempt to construct the spiritual profile (the structure of a person's spiritual life). In the next stages, it is

\footnotetext{
Chmielewski, "Potrzeba metodologii," 37. Cf. Słomka, "Metodologia teologii duchowości," 135-138. See Chmielewski, Metodologiczne problemy, 172-180.

See Słomka, "Metodologia teologii duchowości," 136-137.

See Słomka, "Metodologia teologii duchowości," 136-137. Cf. Chmielewski, "Potrzeba metodologii," 37.
} 
important to ask questions about what has conditioned the already described structure in the "down-up" way, especially its salient elements. The next step is examining one's individual conditioning, which means psychological and socio-cultural conditioning. The method proposed in the present paper, which refers to Atanasio Giuseppe Matanićs comprehensive method, allows us to choose flexibly various tools (borrowed for instance from psychology), adjusted to a specific spiritual experience. That experience is of both theological and phenomenological nature, which requires analyzing theological sources and the person, his or her story and environment. ${ }^{30}$

\subsection{Constructing the Spiritual Profile}

The access to the spiritual profile (the structure of the spiritual life) of a master of the spiritual life is possible above all through written sources (notes, diaries, spiritual treatises, written memories of witnesses, etc.). ${ }^{31}$ In the analysis of that material it is necessary to remember that texts never confront us directly with a spiritual experience. Thus, it is impossible to talk about a pure message. As it is mentioned above, various dynamisms condition the experience accessed by us through the text. Additionally, the researcher, usually unconsciously, assumes his or her own perspective on the analysis. ${ }^{32}$

Werner Günter Jeanrond notices that since the Cartesian return to $\mathrm{Me}$ and the knowledge of the fragility and complexity of the human ego, coming among others from psychoanalysis, the hermeneutics of texts, including theological texts, has lost its strong foundations. The act of interpretation is a complex phenomenon. The above-mentioned theologian highlights the three-dimensional character of that act, which involves the interpretation of the text, the interpretation of the world of the interpreter, and the interpreter's self-interpretation..$^{33}$ The interpretation of the source materials itself may refer to their various aspects: above all, to the understanding of the message, but also to the very author of the text. It may help if we explore the structure of the text or its influence on a group. When we deal with old texts, characterized by a complex historical edition, the basis for understanding their sense is studying the way they were created and passed, as seen, for instance, in the historical-critical method of biblical exegesis. ${ }^{34}$ One of the biggest challenges

30 See Matanić, La spiritualità come scienza, 42-43.

31 The term "master of the spiritual life" is used, among others, by Jan Słomka ("Metodologia teologii duchowości," 131), who points to the fact that the sources of spiritual theology, apart from the constant loci theologici, in many areas are texts of masters. The main parameter of "mastery" is the stability of the fruits of their activity. The term "masters of the spiritual life" includes not only official saints and blesseds, but also the whole group of renowned people of the Church, who are respected as spiritual authority figures.

32 See Bernard, Wprowadzenie do teologii duchowości, 46.

33 Jeanrond, Hermeneutyka teologiczna, 137.

34 See Jeanrond, Hermeneutyka teologiczna, 137-138. 
is the analysis of language with the help of semiotics, especially its branch called semantics, which deals with the relations between the linguistic sign and the described reality, the branch called syntax, which studies the relations between the signs in a sequence constituting the message, and the branch called pragmatics, which analyzes the relations between the sign and its users or the communication situation. ${ }^{35}$

As it has already been said, a researcher that studies texts always introduces his or her own perspective of interpretation into them. It concerns especially those texts that describe human experiences. Personal autonarrations in particular, as well as testimonies of witnesses of the examined person, more than any abstract texts, influence the reader, mainly as a result of the psychological mechanism of identification. If we take into account the nature of the spiritual experience, the full objectivism, which is required from empirical sciences, becomes impossible. A certain degree of subjectivism constitutes an indispensable, and even justified, aspect of the interpretation of spiritual texts. ${ }^{36}$

In the whole process of constructing the structure of the spiritual life it is necessary to pay attention to the quality and credibility of the source materials. The primary sources include texts that were written by the examined subject. Then, the secondary sources are testimonies, that is reflections on his or her activity, written by people from the examined person's environment, who listened to and observed that person's life and work. Inaccessibility of the primary sources may make a reliable description of the spiritual profile impossible. In the analysis of sources categorization is important as it allows us to provide the structure of the most important characteristics of the spiritual life. Before the categories are identified, it is necessary to analyze the frequency and degree of importance of a specific motif (e.g. serving Christ who suffers in the poor; contemplative prayer; sanctification through work) in a reliable way. However, while the identification of the frequency of a particular category appears to be a relatively easy task to perform, the degree of its importance does not. Especially when we analyze the spiritual life in the course of life, pointing to its dynamic character. ${ }^{37}$ Not all source texts are equally important, thus the criterion of frequency should be subordinate to the criterion of importance, and both of them, taken together, give us the full picture.

The stages of the construction of the spiritual profile may be as follows: 1) the analysis of the primary source texts (especially diaries, notes from retreats, etc.); 2) the analysis of the secondary sources, which verify the data from the primary sources (e.g. memories and reflections of witnesses, reliable biographical descriptions); 3) the juxtaposition of the obtained conclusions with the present state of re-

35 See Leszczak, "Semantyka," 97-98. In the process of discovering the sense of spiritual texts, language analysis is used as one of the ways of accessing the reality expressed by means of symbols and analogies subject to various interpretations.

36 Cf. Słomka, "Metodologia teologii duchowości," 137.

37 See Chmielowski, Pisma; Chmielowski, Przewodnik. 
search - at this stage it is justified to use the existing theological, anthropological, and historical works devoted to the examined person; 4) the theological interpretation, which means referring to theological sources and conducting a verification based on the criteria of the Christian experience; 5) naming and classifying the particular categories, including elements convergent with other schools of spirituality, as well as the salient characteristics. Although the agreement with particular criteria verifying the Christian experience and the presence of elements that are shared with other types of spirituality are important, the idea is to demonstrate the uniqueness of the described profile..$^{38}$

The characteristics of the spiritual life, which is prepared and organized in the way described above, constitutes a description of the "ripe fruit" of cooperation with grace, a "top-down" point of reference for further research into its "down-top" conditioning. Obviously, another direction of research is justified. It would be possible to omit the description of the structure of the spiritual life and start with searching for the answer to the question about what has conditioned its elements, each time providing an explanation for their specific character. In this way, the construction of the spiritual profile would be parallel to the demonstration of its natural conditioning. In the present method, we propose to start with the description of the full structure of the spiritual life, without distinguishing between what comes from nature and what comes from grace. While demonstrating the correlation between the natural elements of the spiritual life and the supernatural reality during the further steps, it is not necessary to explain again in detail what the already identified particular categories are. Emphasis should be put on the analysis of the natural structures as such and the identification of connections between them.

The proposed direction of analysis, in which first the spiritual profile is characterized, constitutes a form of protection against the risk of reducing the spiritual life to its natural dimension. However, due to the fact that the spiritual life is the work of grace, the further analysis of its psychological and environmental conditioning may not be able to identify all its underpinnings. The fact that there is no human activity coming from a purely spiritual activity, which is not rooted in the dynamic vital spheres of man and the deep human unconsciousness, does not mean that we leave the sphere of the mystery of God and man. ${ }^{39}$ Due to that reason a certain area of investigation remains unsearchable and impossible to explain. Our caution during the studies on the natural conditioning is based on the humble admittance that it is impossible to find answers to all questions, even if we have access to rich and reliable sources.

38 In the process of verification, the following three types of criteria are important: christological, ecclesiological (especially references to the Magisterium Ecclesiae), and praxeological (the fruit of activity). See Guerra, "Esperienza cristiana," 942-944.

39 See Becattini, "Psicologia e vita spirituale," 2070. 


\subsection{The Psychological Conditioning}

In the description of the psychological conditioning, an important role is played by tools and methods from non-theological disciplines of science. The creation of the personality profile or other psychological aspects of a person's functioning may exceed the competencies of a theologian. Thus, it is justified to use the results of studies conducted by psychologists who are researchers or to invite specialists from auxiliary scientific disciplines to the research group. The only exception is a situation when the theologian is a qualified psychologist or sociologist, which allows him or her to apply the appropriate methods.

In contemporary psychology, emphasis is put on the multicausal models describing personality. In the studies of personality, what helps is using qualitative idiographic methods, especially from the psychobiographic approach. The idiographic methods, unlike the nomothetic ones (quantitative, concerned with measurements), focus on the understanding and describing personality as a unique individuality. ${ }^{40}$ It applies especially to the psychobiographic approach, which gives us the opportunity to use flexibly various tools contributing to the psychological interpretation of a person together with the dynamism of one's psychic life, searching for the reasons of behavior, and taking into account the socio-cultural background. The selection of a theory and research methods should include those characteristics of personality that are of interest to the researcher and are unique to the analyzed profile. ${ }^{41}$

A contemporary authority, recognized internationally, in the field of research on personality is Dan McAdams, who proposes an integrated three-level description model of personality. ${ }^{42}$ In that model, the first level is occupied by personality traits understood as biologically constituted constant dispositions of an individual. On the second level McAdams places characteristic environmental adaptations, which are personal adaptations of an individual to challenges and tasks - they refer to time, place, situation, or a social role. The characteristic adaptations are more dynamic than the more static traits. The third level contains personal identity autonarrations, or stories of life, which provide an individual with the feeling of consistency, goal, and sense. ${ }^{43}$

When looking through McAdams's three-level model at the psychological conditioning of spirituality, a study on the profile of a selected master of the spiritual life

40 See Stemplewska-Żakowicz, Diagnoza psychologiczna, 29-30. Cf. Artymiak, "Psychologia," 35.

41 See Lebuda - Oleś, "Analiza przypadku," 272-273; Mayer - Kovary, "Introduction," 1-7.

42 See McLean, "And the Story Evolves," 325-327.

43 See McAdams, The Person, 10; McAdams, Personal Narratives, 248-250; cf. Adler, "Research Methods"; Oleś, Wprowadzenie do psychologii osobowości, 410-415. Another question is the analysis of others' testimonies concerning the examined subject. Narrations of witnesses constitute an important source of information at the stage of constructing the spiritual profile (see above), but also in the process of creating the personality profile and other characteristic conditions. 
should start with the level of one's personality traits. After that, when the psychological personality profile has been created, it is important to indicate the connections between the traits and the spiritual life with the assumption that the natural dispositions submitted to grace facilitated or inhibited the genesis of particular structures of the spiritual life. The next step is an analysis of the dynamic characteristic conditioning related to the course of life, for instance, the experienced losses, sufferings, and twists of life. Also, it is possible to investigate the identity autonarrations, provided that we have access to them. The autonarrations may show the sense and rank the master of the spiritual life attributes to the experienced events, to himself or herself, and to the reality, in which he or she lives.

Especially in the description of the traits it is a good idea to use a preselected specific theoretical model that corresponds to the character of the examined individual, which will help avoid imprecision in the understanding of concepts (nomenclature). Approved trait models, employed in contemporary personality tests, can be used in the analysis, for example, Paulo Costa and Robert McCrae's five-factor model or Raymond Bernard Cattell's 16 personality factors model. ${ }^{44}$ Those models are used especially in personality questionnaires. In this case, the point is not to take the personality test "on behalf of" the late saint or another master of the spiritual life, but to understand precisely the particular traits. ${ }^{45}$ For instance, when we use such terms as "emotionally irritable" or "diligent," it is a good idea to explain what those traits mean and from which theoretical model they come because in colloquial understanding they may have different and incongruent meanings. ${ }^{46}$

As an example illustrating the above-mentioned propositions we can recall the results of a study on the spiritual life of Saint Albert Chmielowski. His personality can be described by means of Raymond B. Cattell's 16 personality factors model. The analysis of Chmielewski's notes and testimonies of witnesses of his life allow us to identify a high intensity of the following dispositions of that saint: cordiality (factor A), sensitivity (factor I), idealism - creativity and imagination (factor M), individualism (factor Q2), and diligence - being well-organized (factor Q3). ${ }^{47}$ The constellation of those factors taken together describes a person who is strongly emo-

44 See Primi - Ferreira-Rodrigues - Carvalho, "Cattell Personality Factors Questionnaire," 29-37; Smith, "Perfectionism and the Five-Factor Model of Personality," 369-371. In the psychobiographic approach, various theoretical models are used and the qualitative and quantitative methods are combined in personality tests, as seen in George W. Bush's psychobiography by Dan McAdams (George W. Bush and the Redemptive Dream).

45 However, it may be justified to use the so-called competent judges - people who know well the examined subject. They may fill selected personality questionnaires in order to describe the master of the spiritual life. The results may be helpful in the creation of a more reliable personality profile. The form of research that involves the analysis of famous people's personality without direct contacts with them is accepted in psychology. See Henss, Type Nouns and the Five Factor Model of Personality Description, 57-71.

46 See Matuszewski, $W$ zderzeniu z natura, 132-175.

47 See Cattell - Mead, “The Sixteen Personality Factor Questionnaire," 29-37. 
tionally sensitive, creative, imaginative, and at the same time, people-oriented, open to experiences, but also diligent and independent in thinking and acting. When we look for connections with the above-mentioned elements of Chmielowski's spiritual profile, we can conclude that those natural characteristics observed in his life already at a young age left marks in his whole spiritual life, especially in a few spheres: strong emotionality and imagination contributed to the development of his contemplative life, including the experience of the relationship with suffering Christ, cordiality constituted a natural ground for brotherly love, while diligence and individualism influenced the evangelical actio with all its nonconventional forms related to the creation of shelters, living in radical poverty, and sharing home with the homeless, despite the objection and lack of understanding in his environment. ${ }^{48}$

Additionally, in the analysis of the above-mentioned environmental conditioning it is possible to use the various models taken from other branches of psychology, such as personality psychology, clinical psychology, or positive psychology (especially in the analysis of the experiences of crisis and suffering). ${ }^{49}$

\subsection{The Socio-Cultural (Historical) Conditioning}

Apart from the psychological conditioning, related to the personality of an individual, the spiritual life is also rooted in culture. ${ }^{50}$ When looking for the socio-cultural conditioning, it is important to analyze the environment of growing up, especially the family background, but also the peer environment, which is connected to significant relationships, as well as the cultural environment. It is not always possible to reconstruct the educational environment, although there we can find the primary natural grounds for the development of holiness. In order to study the educational environment it is advisable to employ the achievements of psychology, pedagogy, and sociology, which help emphasize those significant moments in life which influence its further course. The person's experiences, education, development of interests, and the read literature - all those natural factors leave marks that can be identified in the spiritual profile. The same refers to the spirituality (forms of devotion, asceticism etc.) encountered by the master of the spiritual life. In line with the knowledge coming from social sciences, the first experiences at an early age influence the following

48 Demonstrating connections between the structure of the spiritual life and its psychological conditioning requires an earlier description of the spiritual profile and the structure of personality traits in order to show mutual correlations. See Cattell - Mead, "The Sixteen Personality Factor Questionnaire," 314-315. An example is Elisabeth Mika's study ("Adam Chmielowski's Journey through Positive Disintegration," 186-218), which is based on Kazimierz Dąbrowski's theory of positive disintegration, used in the description of the process of positive adaptation to life in the case of Adam Chmielowski.

50 Culture should be understood as any kind of human achievements preserved in various fields of activity (familial, social, legal, economic, political, educational, etc.). Thus, it is the whole of human behaviors, actions, and their results. Piwowarski, "Kultura," 91-92; GS 53; Witek, Teologia życia duchowego, 75. Cf. Kawecki, "Personalistyczna koncepcja teologii kultury," 194-196. 
spheres of personality in a more intensive way: cognitive (beliefs concerning the person and the world), emotional, behavioral, and volitional.

When it comes to cultural conditioning, the direction of study may go from the influences of local culture, to national culture, to international culture. In the analysis, it is necessary to consult historical works describing the atmosphere of the era, as well as the philosophical, social, and political tendencies, which may influence the spiritual life. Studying the historical sources or works devoted to them allows us to locate the master in his or her Sitz im Leben. The characteristics of culture and society juxtaposed with the notes and diaries of the examined person enables us to find in both their content and language, that is the vocabulary and concepts used, the very sphere of the spiritual experience that is marked by the historical era.

\section{Concluding Remarks}

The present paper focuses on the methodological aspects of the natural conditioning of the spiritual life. We have identified and emphasized three important areas of the specific character of the research on that conditioning: 1) comprehensiveness, 2) interdisciplinarity, 3) correlativity.

When it comes to its comprehensiveness, the research process assumes a selection of adequate methods that allow us to capture, if possible, all the natural dynamisms combined together: psychological and socio-cultural. In this way, we are able to create the whole picture instead of focusing on only selected aspects, either historical or psychological. Thus, the aim is to take the holistic perspective on the dynamisms that shape the spiritual life, with the assumption that, due to their dynamic character, all natural factors interact with each other. Only when we combine them together can we create the multidimensional and layered structure of mutual relationships, which reveals the panorama of the conditioning of the spiritual life. When answering the question about what has shaped a particular structure it would be an oversimplification to claim that it was only the atmosphere of the era, or a particular personality trait, or only a loss experienced at a young age.

The direction of analysis which allows us to take the holistic perspective on the natural grounds of spirituality and which employs both the deductive and inductive approach should include the following steps: (1) construction of the spiritual profile, (2) description of the psychological conditioning, which demonstrates its connections with the constructed structure of the spiritual life, (3) description of the socio-cultural conditioning and its correlation with the structural elements of the spiritual profile. Searching for the grounds of the spiritual life should start with the dynamisms that have the strongest influence on the subject (temperament, experiences from childhood and adolescence, and significant personal experiences) and 
continue with more external dynamisms (the influence of the educational and local environment, national and international culture, etc.).

The interdisciplinary character of the research on the natural conditions of the spiritual life is indispensable to understand the complexity of the examined subject. The choice of research tools, especially psychological, allows us to capture better both the relatively stable (static) personality (here an important role is played by the models of personality traits) and the subject's dynamic character (e.g. the experienced losses, traumas, crises, successes). When it comes to the dynamic aspect, it is possible to use theoretical models taken from various branches of psychology (e.g. Kazimierz Dąbrowski’s model of positive disintegration, Erik Erikson's stages of development).

Thanks to correlativity, that is interdependence between what is natural and the life of grace, the whole research process aims at demonstrating the identified relationships (correlations) between selected aspects of the spiritual life and its various grounds. Those connections between the natural elements and the supernatural life allow us to present the depth, complexity, and richness of the God-man synergy. As it has been mentioned above, the description of the conditioning of the spiritual life is not a definite judgment, but it assumes a smaller or bigger probability. We need to emphasize that the mutual connection between nature and grace does not describe a cause and effect relationships, but a mutual correlation. The divine reality and the human reality are truly interconnected, although God has priority here, and the two preserve the real distinctiveness of their nature, with no mixing between them. ${ }^{51}$

\section{Bibliography}

Adler, J.M. et al., "Research Methods for Studying Narrative Identity: A Primer," Social Psychological and Personality Science 8/5 (2017) 519-529.

Artymiak, M., "Psychologia pomiędzy podejściem ilościowym i jakościowym - u początków nurtu narracyjnego i psychobiograficznego," Doświadczenia człowieka (eds. J. Iskra M. Artymiak) (Kraków: Petrus 2013) 27-41.

Becattini, C., "Psicologia e vita spirituale," Dizionario enciclopedico di spiritualità (ed. E. Ancilli) (Roma: Città Nuova 1995) III, 2065-2078.

Bernard od Matki Bożej, Duchowość Brata Alberta (Kraków: Drukarnia "Powściągliwość i Praca" 1938).

Bernard, C.A., Teologia spirituale (Roma: Edizioni Paoline 1982).

Bernard, C.A., Wprowadzenie do teologii duchowości (Kraków: WAM 1996).

51

Cf. Vagaggini, Teologia, 163. 
Bouyer, L., Wprowadzenie do życia duchowego. Zarys teologii ascetycznej i mistycznej (Warszawa: PAX 1982).

Catalan, J.F., Esperienza spirituale e psicologia (Cinisello Balsamo: Edizioni Paoline 1994).

Cattell, H.E.P. - Mead, A.D., "The Sixteen Personality Factor Questionnaire (16PF)," The SAGE Handbook of Personality Theory and Assessment. II. Personality Measurement and Testing (eds. G.J. Boyle - G. Matthews - D.H. Saklofske) (London: SAGE 2008) 135-159.

Chmielewski, M., Metodologiczne problemy posoborowej teologii duchowości katolickiej (Lublin: Redakcja Wydawnictw KUL 1999).

Chmielewski, M., "Potrzeba metodologii w teologii duchowości," Duchowość w Polsce 12 (2010) 29-39.

Chmielewski, M., “Życie duchowe,” Leksykon duchowości katolickiej (ed. M. Chmielewski) (Lublin - Kraków: Wydawnictwo „M” 2002) 975-978.

Chmielowski, A., Pisma Adama Chmielowskiego św. Brata Alberta (ed. A. Faron) (Kraków: Wydawnictwo Instytutu Teologicznego Księży Misjonarzy 2004).

Chmielowski, A., Przewodnik (większy) do Reguty III zakonu św. Franciszka Serafickiego (Kraków: Drukarnia „Czasu” 1888).

Francis, Apostolic Constitution Veritatis Gaudium (2017).

Garrigou-Lagrange, R., Trzy okresy życia wewnętrznego wstępem do życia w niebie, 4 ed. (Niepokalanów: Wydawnictwo Ojców Franciszkanów 2014).

Goya, B., Psicologia e vita spirituale. Sinfonia a due mani (Bologna: Edizioni Dehoniane Bologna 2001).

Greshake, G., Wprowadzenie do nauki o łasce (Kraków: WAM 2005).

Guardini, R., Wolność - łaska - los. Rozważanie o sensie istnienia (Kraków: Znak 1995).

Guerra, A., "Esperienza cristiana," Dizionario enciclopedico di spiritualità (ed. E. Ancilli) (Roma: Città Nuova Editrice 1995) II, 934-945.

Henss, R., “Type Nouns and the Five Factor Model of Personality Description," European Journal of Personality 12 (1998) 57-71.

Imoda, F., Odkryj w sobie tajemnice (Kraków: WAM 2010).

Jeanrond, W.G., Hermeneutyka teologiczna. Rozwój i znaczenie (Kraków: WAM 1999).

Kawecki, W., "Personalistyczna koncepcja teologii kultury," Studia Theologica Varsaviensia 44/1 (2006) 191-204.

Ladaria, L.F., Wprowadzenie do antropologii teologicznej (Kraków: WAM 1997).

Lebuda, I. - Oleś, P., "Analiza przypadku - studium psychologiczne umysłów niepospolitych," Diagnoza psychologiczna. Kompetencje i standardy. Wybrane zagadnienia (eds. M. Filipiak et al.) (Warszawa: Pracownia Testów Psychologicznych Polskiego Towarzystwa Psychologicznego 2015) 271-292.

Leszczak, O., "Semantyka - syntaktyka - pragmatyka: funkcjonalno-pragmatyczna rewizja pojęć," Język poza granicami języka. II. Semantyka a pragmatyka: spór o pierwszeństwo. 1. Aspekty lingwistyczno-semiotyczne (ed. A. Kiklewicz) (Olsztyn: Centrum Badań Europy Wschodniej UWM w Olsztynie 2011) 97-109.

Lorda, J.L., Łaska Boża (Lublin: Wydawnictwo KUL 2012).

Matanić, A.G., La spiritualità come scienza. Introduzione metodologica allo studio della vita spirituale cristiana (Cinisello Balsamo: Edizioni Paoline 1990). 
Matuszewski, K., W zderzeniu z natura - świętość Brata Alberta. Naturalne uwarunkowania życia duchowego świętego Alberta Chmielowskiego (Katowice: Wydawnictwo UŚ 2019).

Mayer, C.-H. - Kovary, Z., "Introduction: New Perspectives in Psychobiography," New Trends in Psychobiography (eds. C.-H. Mayer - Z. Kovary) (Cham: Springer 2019) 1-7.

Mika, E., "Adam Chmielowski's Journey through Positive Disintegration," Developmental Potential - From Theory to Practice: Educational and Therapeutic perspectives. Dabrowski Proceedings. The Sixth International Congress of the Institute For Positive Disintegration in Human Development (ed. B. Tiller) (Unpublished manuscript; Calgary 2004) 186-218.

McAdams, D., George W. Bush and the Redemptive Dream. A Psychological Portrait (New York: Oxford University Press 2011).

McAdams, D., The Person. An Integrated Introduction to Personality Psychology (New York: Wiley 2002).

McAdams, D., "Personal Narratives and the Life Story," Handbook of Personality. Theory and Research (eds. O.P. John - R.W. Robins - L.A. Pervin) (New York: Guildford 2008) 242-262.

McLean, K.C., "And the Story Evolves: The Development of Personal Narratives and Narrative Identity," Personality Development Across the Lifespan (ed. J. Specht) (Cambridge, MA: Academic Press 2017) 325-338.

Oleś, P., Wprowadzenie do psychologii osobowości, 3 ed. (Warszawa: Scholar 2011).

Perzyński, A., "Natura i łaska," Encyklopedia katolicka (eds. E. Gigilewicz et al.) (Lublin: Towarzystwo Naukowe KUL 2009) XIII, 807-808.

Piwowarski, W., "Kultura," Słownik katolickiej nauki społecznej (ed. W. Piwowarski) (Warszawa: PAX - Palabra 1993) 91-92.

Primi, R. - Ferreira-Rodrigues, C.F. - Carvalho L.F., "Cattell Personality Factors Questionnaire (CPFQ): Construction and Preliminary Study," Paidéia 57 (2014) 29-37.

Rulla, L.M. - Imoda, F. - Ridick, J., Antropologia della vocazione cristiana. II. Conferme esistenziali (Casale-Monferrato: Edizioni Dehoniane Bologna 1994).

Słomka, J., "Metodologia teologii duchowości," Śląskie Studia Historyczno-Teologiczne 50/1 (2017) 129-142.

Smith, M.M. et al., "Perfectionism and the Five-Factor Model of Personality: A Meta-Analytic Review," Personality and Social Psychology Review 23/4 (2019) 367-390.

Stemplewska-Żakowicz, K., Diagnoza psychologiczna. Diagnozowanie jako kompetencja profesjonalna (Gdańsk: Gdańskie Wydawnictwo Psychologiczne 2011).

Stinissen, W., Noc jest mi świattem. Św. Jan od Krzyża na nowo odczytany, 4 ed. (Kraków: Wydawnictwo Karmelitów Bosych 2010).

Szymik J., Teologia. Rozmowa o Bogu i człowieku (Lublin: Wydawnictwo KUL 2008).

Urbański, S., "Metodologia teologii duchowości," Studia Nauk Teologicznych PAN 2 (2007) 215-234.

Urbański, S., "Przedmowa do II wydania polskiego," R. Garrigou-Lagrange, Trzy okresy życia wewnętrznego wstępem do życia w niebie, 4 ed. (Niepokalanów: Wydawnictwo Ojców Franciszkanów 2014) 5-7.

Vagaggini, C., Teologia. Pluralizm teologiczny (Kraków: Homini 2005).

Vaticanum II, Pastoral Constitution on the Church in the Modern World Gaudium et Spes (1965) (=GS). 
Witek, S., Teologia życia duchowego (Lublin: Towarzystwa Naukowego KUL 1986).

Zuberbier, A., Relacja Natura - nadprzyrodzoność (Warszawa: Akademia Teologii Katolickiej 1973). 
